\title{
Effect of the summer monsoon on aerosols at two measurement stations in Northern India - Part 2: Physical and optical properties
}

\author{
A.-P. Hyvärinen ${ }^{1}$, T. Raatikainen ${ }^{1, *}$, M. Komppula ${ }^{2}$, T. Mielonen ${ }^{2}$, A.-M. Sundström ${ }^{3}$, D. Brus ${ }^{1,4}$, T. S. Panwar ${ }^{5}$, \\ R. K. Hooda ${ }^{5}$, V. P. Sharma ${ }^{5}$, G. de Leeuw ${ }^{1,3}$, and H. Lihavainen ${ }^{1}$ \\ ${ }^{1}$ Finnish Meteorological Institute, Erik Palménin aukio 1, P.O. Box 503, 00101, Helsinki, Finland \\ ${ }^{2}$ Finnish Meteorological Institute, Yliopistonranta 1F, P.O. Box 1627, 70211 Kuopio, Finland \\ ${ }^{3}$ Department of Physics, University of Helsinki, P.O. Box 64, 00014 Helsinki, Finland \\ ${ }^{4}$ Laboratory of Aerosol Chemistry and Physics, Institute of Chemical Process Fundamentals Academy of Sciences of the \\ Czech Republic, Rozvojová 135, 16502 Prague 6, Czech Republic \\ ${ }^{5}$ The Energy and Resources Institute (TERI), Darbari Seth Block, IHC Complex, Lodhi Road, New Delhi 110 003, India \\ * currently at: School of Earth \& Atmospheric Sciences, Georgia Institute of Technology, 311 Ferst Drive, Atlanta, GA \\ 30332-0340, USA
}

Received: 21 December 2010 - Published in Atmos. Chem. Phys. Discuss.: 19 January 2011

Revised: 27 June 2011 - Accepted: 10 July 2011 - Published: 15 August 2011

\begin{abstract}
Aerosol physical and optical properties were measured at two locations in northern India. The first measurement station was a background site in Mukteshwar, about $350 \mathrm{~km}$ northeast of New Delhi, in the foothills of the Indian Himalayas, with data from 2006 to 2009. The second measurement site was located in Gual Pahari, about $25 \mathrm{~km}$ south of New Delhi, with data from 2008 to 2009. At both stations, the average aerosol concentrations during the monsoon were decreased by $40-75 \%$ compared to the pre-monsoon average concentrations. The decrease varied with the total local rainfall. In Mukteshwar, the monsoon season removed particles from all size classes, due to a combination of rain scavenging and activation to cloud and mountain fog droplets. The scavenging by rain is least effective for the size range of the accumulation mode particles. In Gual Pahari, this was the only major wet removal mechanism and, as a result, the accumulation mode particles were less effectively removed. Aerosol concentrations during the early monsoon were found to be affected by mineral dust which in Gual Pahari was observed as an increased particle volume at a diameter around 3-4 $\mu \mathrm{m}$. The single scattering albedo varied from 0.73 to 0.93 during the monsoon season, being slightly lower in Gual Pahari than in Mukteshwar. This is due to the fact that Gual Pahari resided closer to high anthropogenic black carbon emissions. As the absorbing particles are typically in the accumulation mode, they were not effectively removed by rain
\end{abstract}

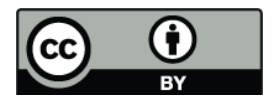

Correspondence to: A.-P. Hyvärinen (antti.hyvarinen@fmi.fi) scavenging. The aerosol columnar properties, which were measured in Gual Pahari, showed a somewhat different seasonal behaviour compared to the surface measurements, with the aerosol optical depth increasing to an annual maximum in the early monsoon season.

\section{Introduction}

The importance of the Asian Summer Monsoon is well known. In addition to being a water supply and providing agricultural irrigation, the monsoon brings a relief to the severe pollution build up during the winter and spring in the area.

In recent years it has become evident that aerosols may influence the precipitation patterns of the Summer Monsoon. This may be especially important in Southern Asia, since the area suffers from an intense and persistent particulate pollution called the "brown cloud" (e.g., Lelieveld et al., 2001; Nakajima et al., 2007; Ramanathan et al., 2007). The influence of the brown cloud on monsoon patterns has been investigated in numerous studies. Probably the most famous work on this is the so-called "Elevated Heat Pump" hypothesis (EHP) (Lau et al., 2006). According to the EHP hypothesis, absorbing aerosols accumulate against the southern slopes of the Himalayas in the pre-monsoon season, thus, modulating the tropospheric temperature gradient. The reinforced meridional temperature gradient would lead to an early onset of monsoon and intensified rainfall during June and July. Several studies have later attempted to find further evidence to

Published by Copernicus Publications on behalf of the European Geosciences Union. 
support or criticize this hypothesis (e.g., Lau and Kim, 2006; D. Liu et al., 2008; Z. Liu et al., 2008; Meehl et al., 2008; Ramanathan and Carmichael, 2008; Randles and Ramaswamy, 2008; Bollasina et al., 2008; Collier and Zhang, 2009; Gautam et al., 2009a, b; Kuhlmann and Quaas, 2010; Nigam and Bollasina, 2010; Lau and Kim, 2010). The EHP hypothesis is certainly not the only aerosol mechanism affecting the summer monsoon precipitation. A general challenge in all these studies is that the aerosol effects are not simply confined to direct or indirect effects alone, but they can be coupled through feedback processes (Huang et al., 2007), and also semi-direct effects may become important in certain conditions (Nigam and Bollasina, 2010). The net effect of all these mechanisms is not known, and due to both spatial and temporal variability of aerosols, the error sources in these simulations are large. Therefore, observational evidence is of great importance to elucidate the effects of aerosols on monsoon. These reasons provide a comprehensive motivation to study the aerosol-monsoon interactions in the area.

In this paper, we focus on the investigation of the aerosol physical and optical properties and their development during the Summer Monsoon seasons at two stations in India; Gual Pahari in the Indo-Gangetic plains and Mukteshwar in the Himalayan foothills. The companion paper (Hyvärinen et al., 2011) focused on particulate matter and black carbon concentrations. We quantify the effect that the monsoon has on the aerosol concentrations and properties, and compare the differences between different years at the two locations. The data presented here will be useful for modelling studies of aerosol-monsoon interactions and provides information of the aerosol properties during the monsoon.

\section{Measurement sites and methods}

The first measurement station was a background site in Mukteshwar $\left(29^{\circ} 26^{\prime} \mathrm{N}, 79^{\circ} 37^{\prime} \mathrm{E}\right.$, Fig. 1), about $350 \mathrm{~km}$ northeast of New Delhi in India. The site was located at $2180 \mathrm{~m}$ above sea level in a rural region at the Himalaya Mountains. The second measurement site was located in Gual Pahari $\left(28.43^{\circ}\right.$ North, 77.15 ${ }^{\circ}$ East, 243 ma.s.1., Fig. 1), Gurgaon, about $25 \mathrm{~km}$ south of New Delhi. The surroundings represented a semi-urban environment. Both sites have been described in detail before, see Hyvärinen et al. (2009) and Hyvärinen et al. (2010). The presented results cover the years from 2006 to 2009 for Mukteshwar and from 2008 to 2009 for Gual Pahari.

\subsection{Instruments}

The parameters measured at Mukteshwar included the particle number size distribution from $10 \mathrm{~nm}$ to $800 \mathrm{~nm}$ (DMPS), $\mathrm{PM}_{2.5}$ and $\mathrm{PM}_{10}$ concentrations (on-line beta-attenuation analyzers), aerosol scattering coefficient (Nephelometer at $525 \mathrm{~nm}$ ), black carbon concentration/absorption coefficient

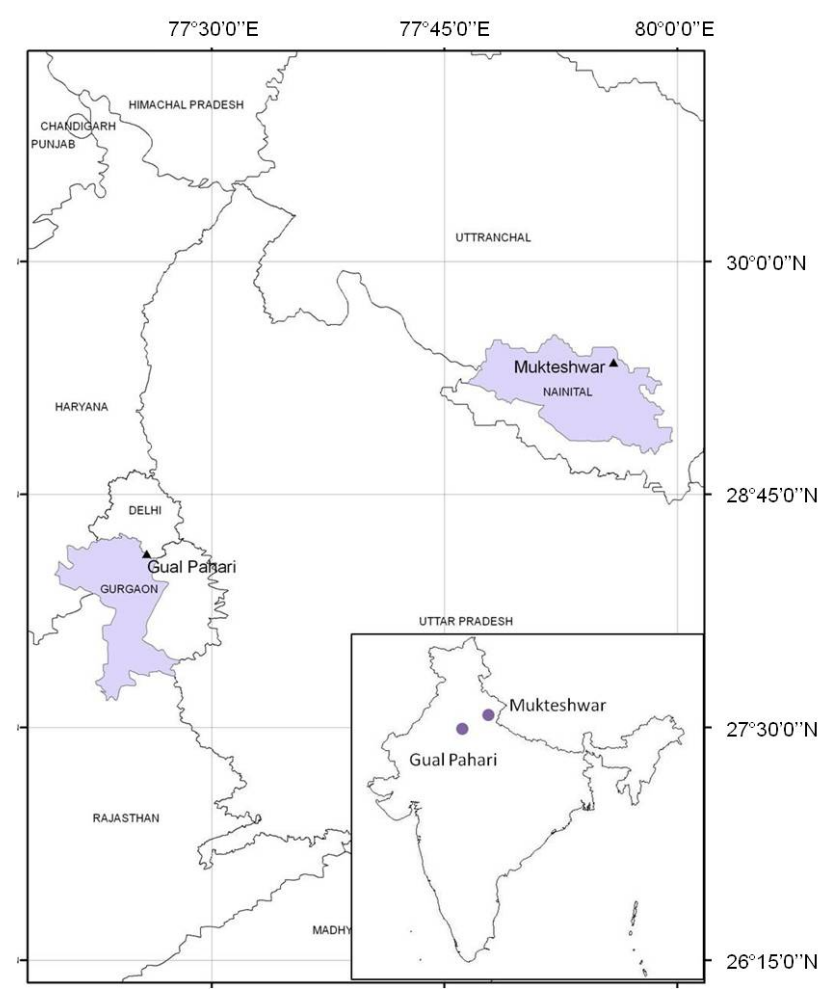

Fig. 1. Map of the measurements stations.

(7-wavelength Aethalometer) and meteorological parameters. The measurements and instruments at the site are presented in more detail by Hyvärinen et al. (2009) and Komppula et al. (2009). All instruments sampled from a single sampling line (except the particle mass monitors which each had their own inlets), with a $\mathrm{PM}_{2.5}$ inlet located at about $5 \mathrm{~m}$ above ground level and about $2 \mathrm{~m}$ above the roof of the station building.

A similar sampling procedure was utilized in Gual Pahari. Two separate inlets with $\mathrm{PM}_{2.5}$ and $\mathrm{PM}_{10}$ cut-off were used for sampling of the respective aerosol mass concentrations (on-line scattering/beta-attenuation hybrid analyzers). The measurements which were conducted from the main inlet with a $\mathrm{PM}_{10}$ cut-off were: particle number size distribution over the diameter range $4 \mathrm{~nm}-10 \mu \mathrm{m}$ (twin-DMPS and APS), black carbon concentration/absorption coefficient (MAAP at $637 \mathrm{~nm}$ ) and aerosol scattering coefficient (Nephelometer at $520 \mathrm{~nm}$ ). Meteorological parameters were also measured. A more detailed presentation can be found in Hyvärinen et al. (2010). In addition to the in situ measurements, a Raman Lidar was operational during 2008 (see Komppula et al., 2010) and a Cimel sunphotometer during 2009. Cimel measurements were made as a part of the Aerosol Robotic Network, AERONET (e.g., Holben et al., 1998). 


\subsection{Data processing}

The measured data was saved as five minute averages. The five minute data was checked with outliers and obvious instrument malfunctions periods removed. The data was then averaged to one hour with the condition that each hour had more than 25 min of data. All longer time averages were calculated from the hourly data, which was also converted to STP-conditions. One month averages were only calculated if the data covered more than $30 \%$ of the time. For seasonal analyses, the year was divided into four seasons: winter (December-February), pre-monsoon (March-onset of monsoon), monsoon season and post-monsoon (withdrawal of monsoon-November). When seasonal averages were calculated, the determined onset and withdrawal dates defined the monsoon season for each year separately. Again a $30 \%$ data coverage level was demanded, with an exception to the Gual Pahari DMPS size distribution data, which we wanted to present despite the low data coverage. The $1 \mathrm{~h}$ data coverage for the low size range $(4-58 \mathrm{~nm})$ and high size range $(31-850 \mathrm{~nm})$ of the twin-DMPS was $24 \%$ and $33 \%$, respectively.

We calculated the ratio of Aitken-mode particles (25$75 \mathrm{~nm})$ to accumulation mode $(75-800 \mathrm{~nm})$ particles, $N_{\text {ait }} / N_{\text {acc }}$. Most of the aerosol particles emitted by various combustion processes are in the size range of $15-100 \mathrm{~nm}$ (Chang et al., 2004). The ratio $N_{\text {ait }} / N_{\text {acc }}$ tends to decrease with increasing distance from major source areas of combustion-derived aerosols, as they grow by condensation and cloud processing toward the accumulation mode. New particle formation increases $N_{\text {ait }} / N_{\text {acc }}$ ratio because of the growth of nucleation mode particles into the Aitken mode.

The optical coefficients are presented for the wavelength of about $520 \mathrm{~nm}$. From Mukteshwar, the absorption was obtained directly from the Aethalometer channel $520 \mathrm{~nm}$. However, at Gual Pahari, the MAAP measured the absorption at $637 \mathrm{~nm}$ (Müller et al., 2011). We converted this absorption coefficient to match $520 \mathrm{~nm}$ by assuming a wavelength dependence of absorption $\sigma_{\mathrm{abs}}=\lambda^{-\alpha}$ (Bergstrom, 1973; Bohren and Hufman, 1983), with $\alpha=1.2$ as measured at the Mukteshwar station (Hyvärinen et al., 2009). This value represents a mixture of absorbing materials with mostly black carbon (which has $\alpha=1.0$, Bergstrom et al., 2007), and some organic carbon and/or mineral dust. We tested the sensitivity of $\alpha$ to the SSA by testing values between 1 and 2. The effect on SSA was less than $5 \%$.

\section{Results}

\subsection{General features}

The monsoon characteristics are presented in Fig. 2. During the four measurement years, there were contrasting monsoon seasons; with both excessive rain and drought. Rainfall was

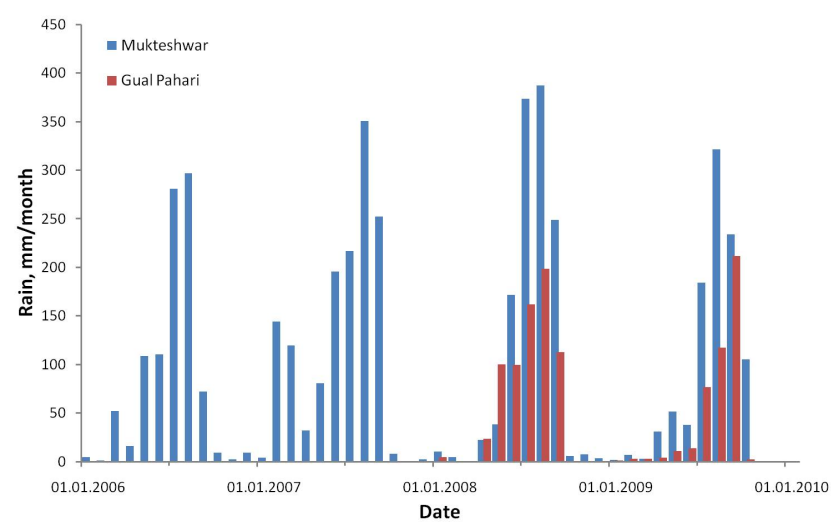

Fig. 2. Monthly rain accumulation during the running of the measurement stations.

more intensive in Mukteshwar than in Gual Pahari, probably due to the mountain location, as air masses flowing uphill are more likely to form clouds and rain. Year 2008 exhibited the most rainfall, and an early monsoon onset date of 16 June, which is one of the earliest onset dates recorded in the area with rainfall data available since 1901 (Tyagi et al., 2009). The weakest monsoon occurred in 2006. A thorough trajectory analysis of incoming air masses was reported by Raatikainen et al. (2011). In summary, during the monsoon season both sites have air masses from both Bay of Bengal (SE) and Arabian Sea (SW) directions. At other times, westerly air masses dominate.

The aerosol concentrations and the subsequent optical coefficients in the pre-monsoon season were highest in 2008 and 2009 (Table 1), with an exception to absorption coefficient which was highest in 2007. Lowest pre-monsoon concentrations occurred in 2006. The average aerosol concentrations and optical coefficients during monsoon were decreased by about 40-75\% compared to the pre-monsoon average concentrations at both stations (Fig. 3), having a linear relationship with the total rainfall of the yearly monsoon season. The most effective decrease of the aerosol concentrations were observed during 2008 in Mukteshwar. During 2008, the rain amounts were the highest of the study period. The relative decrease seems nearly independent of the measurement location and can be estimated from the rain accumulation alone by an accuracy of $\pm 10 \%$. During the post-monsoon season, concentrations rose again. In Gual Pahari, the post monsoon averages were higher than the premonsoon averages. In Mukteshwar, however, the post monsoon averages were lower than the pre-monsoon averages. This behaviour can be explained by the lower boundary layer height in the post-monsoon season (Raatikainen et al., 2011). In the following sections, we will detail the behaviour of different aerosol properties during and around monsoon. 
Table 1. Pre-monsoon, monsoon and post-monsoon average aerosol properties in Mukteshwar and Gual Pahari. $30 \%$ hourly data coverage is demanded. \pm denotes standard deviation calculated from the hourly data.

\begin{tabular}{|c|c|c|c|c|c|c|c|c|}
\hline $\begin{array}{l}\text { Mukteshwar } \\
\text { Season }\end{array}$ & Year & $\begin{array}{r}\text { Abs coeff. }{ }^{\mathrm{a}} \\
\mathrm{Mm}^{-1}\end{array}$ & $\begin{array}{r}\text { Scat coeff. }{ }^{\mathrm{b}} \\
\mathrm{Mm}^{-1}\end{array}$ & $\begin{array}{r}N_{\text {tot }} \\
\# / \mathrm{cm}^{3}\end{array}$ & $\begin{array}{r}N<25 \mathrm{~nm} \\
\# / \mathrm{cm}^{3}\end{array}$ & $\begin{array}{r}N 25<d<75 \mathrm{~nm} \\
\# / \mathrm{cm}^{3}\end{array}$ & $\begin{array}{r}N>75 \mathrm{~nm} \\
\# / \mathrm{cm}^{3}\end{array}$ & \\
\hline $\begin{array}{l}\text { Pre } \\
\text { Monsoon } \\
\text { Post }\end{array}$ & 2006 & $\begin{array}{r}21.6 \pm 14.6 \\
7.4 \pm 5.2 \\
18.2 \pm 12.7\end{array}$ & $\begin{array}{l}88.6 \pm 54.0 \\
42.3 \pm 40.6 \\
96.3 \pm 93.0\end{array}$ & $\begin{array}{r}4613 \pm 2531 \\
2023 \pm 876 \\
3108 \pm 1570\end{array}$ & $\begin{array}{r}274 \pm 581 \\
54 \pm 56 \\
69 \pm 88\end{array}$ & $\begin{array}{r}1715 \pm 1230 \\
730 \pm 323 \\
844 \pm 573\end{array}$ & $\begin{array}{r}2976 \pm 1534 \\
1228 \pm 639 \\
2125 \pm 1124\end{array}$ & \\
\hline $\begin{array}{l}\text { Pre } \\
\text { Monsoon } \\
\text { Post }\end{array}$ & 2007 & $\begin{array}{r}25.8 \pm 16.7 \\
8.9 \pm 5.1 \\
19.6 \pm 14.0\end{array}$ & $\begin{array}{l}96.7 \pm 57.5 \\
56.8 \pm 40.6 \\
97.4 \pm 82.5\end{array}$ & $\begin{array}{l}5761 \pm 3447 \\
2653 \pm 1011 \\
4010 \pm 1965\end{array}$ & $\begin{array}{r}298 \pm 736 \\
68 \pm 75 \\
118 \pm 142\end{array}$ & $\begin{array}{r}1886 \pm 1453 \\
976 \pm 473 \\
1101 \pm 636\end{array}$ & $\begin{array}{r}3545 \pm 2111 \\
1605 \pm 699 \\
2446 \pm 1236\end{array}$ & \\
\hline $\begin{array}{l}\text { Pre } \\
\text { Monsoon } \\
\text { Post }\end{array}$ & 2008 & $\begin{array}{r}25.1 \pm 18.9 \\
6.9 \pm 4.9 \\
18.3 \pm 11.4\end{array}$ & $\begin{array}{r}133.8 \pm 95.0 \\
34.3 \pm 37.5 \\
104.9 \pm 87.5\end{array}$ & $\begin{array}{r}6901 \pm 4054 \\
1909 \pm 900 \\
3195 \pm 2683\end{array}$ & $\begin{array}{r}393 \pm 795 \\
66 \pm 70 \\
125 \pm 208\end{array}$ & $\begin{array}{r}2133 \pm 1513 \\
726 \pm 318 \\
999 \pm 1225\end{array}$ & $\begin{array}{r}4365 \pm 2907 \\
1115 \pm 640 \\
2065 \pm 1397\end{array}$ & \\
\hline $\begin{array}{l}\text { Pre } \\
\text { Monsoon } \\
\text { Post }\end{array}$ & 2009 & $25.7 \pm 16.6$ & $\begin{array}{r}128.7 \pm 119.8 \\
74.1 \pm 60.3 \\
31.5 \pm 26.5\end{array}$ & $\begin{array}{l}6395 \pm 4841 \\
3244 \pm 1819 \\
2124 \pm 1234\end{array}$ & $\begin{array}{l}368 \pm 685 \\
119 \pm 169 \\
156 \pm 248\end{array}$ & $\begin{array}{r}2176 \pm 1831 \\
1266 \pm 781 \\
777 \pm 464\end{array}$ & $\begin{array}{r}3824 \pm 3448 \\
1929 \pm 1222 \\
1258 \pm 721\end{array}$ & \\
\hline $\begin{array}{l}\text { Gual Pahari } \\
\text { Season }\end{array}$ & Year & $\begin{array}{r}\text { Abs coeff. } \\
\mathrm{Mm}^{-1}\end{array}$ & $\begin{array}{r}\text { Scat coeff. }{ }^{\mathrm{d}} \\
\mathrm{Mm}^{-1}\end{array}$ & $\begin{array}{r}N_{\text {tot }} \\
\# / \mathrm{cm}^{3}\end{array}$ & $\begin{array}{r}N<25 \mathrm{~nm} \\
\# / \mathrm{cm}^{3}\end{array}$ & $\begin{array}{r}N 25<d<75 \mathrm{~nm} \\
\# / \mathrm{cm}^{3}\end{array}$ & $\begin{array}{r}N>75 \mathrm{~nm} \\
\# / \mathrm{cm}^{3}\end{array}$ & 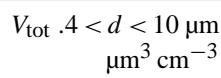 \\
\hline $\begin{array}{l}\text { Pre } \\
\text { Monsoon } \\
\text { Post }\end{array}$ & 2008 & $62.8 \pm 51.3$ & $843.9 \pm 626.6$ & & & & $6342 \pm 4104$ & $77.2 \pm 57.5$ \\
\hline $\begin{array}{l}\text { Pre } \\
\text { Monsoon } \\
\text { Post }\end{array}$ & 2009 & $\begin{array}{r}60.8 \pm 49.7 \\
28.6 \pm 26.9 \\
109.0 \pm 59.9\end{array}$ & $\begin{array}{r}312.7 \pm 253.2 \\
1235.5 \pm 1291.2\end{array}$ & $25860 \pm 11707$ & $1950 \pm 4046$ & $6904 \pm 4299$ & $\begin{array}{l}6953 \pm 4835 \\
5607 \pm 4059 \\
1696 \pm 9486\end{array}$ & $\begin{array}{l}50.6 \pm 45.4 \\
29.2 \pm 20.6 \\
66.0 \pm 43.8\end{array}$ \\
\hline
\end{tabular}

Measured at ${ }^{\mathrm{a}} 520 \mathrm{~nm}^{\mathrm{b}} 525 \mathrm{~nm}^{\mathrm{c}} 637 \mathrm{~nm}^{\mathrm{d}} 520 \mathrm{~nm}$.

\subsection{Aerosol size distribution}

The number size distributions during the pre-monsoon, monsoon and post-monsoon seasons are presented for both stations in Fig. 4a and c, together with the monthly average modal concentrations (Fig. $4 \mathrm{~b}$ and d).

In Mukteshwar, the average number size distribution was unimodal at all times. The total particle concentrations decreased by about $50-75 \%$ from the pre-monsoon to monsoon season, depending on the amount of rainfall. The nucleation mode decreased by an average of $77 \%$, the Aitken mode by $53 \%$ and the accumulation mode by $60 \%$. In addition to the concentration decrease, the seasonal average mode diameter decreased from the pre-monsoon value of $\sim 101 \mathrm{~nm}$ to the monsoon average of $\sim 81 \mathrm{~nm}$. The average ratio of Aitken-mode particles $(25-75 \mathrm{~nm})$ to accumulation mode $(75-800 \mathrm{~nm})$ particles, $N_{\text {ait }} / N_{\text {acc }}$ increased from the pre-monsoon time value of 0.58 to monsoon time value of 0.65 . An increased ratio points towards fresher emissions or increased removal of the accumulation mode particles. New particle formation was not observed in Mukteshwar during the monsoon season (Neitola et al., 2011). No major interannual variations were found in the monsoon season modal concentration ratios, indicating that the total accumulated rainfall had little influence on this. During post-monsoon the average value for the mode diameter was $\sim 108 \mathrm{~nm}$. The ratio of Aitken-mode to accumulation mode particles, $N_{\text {ait }} / N_{\text {acc }}$

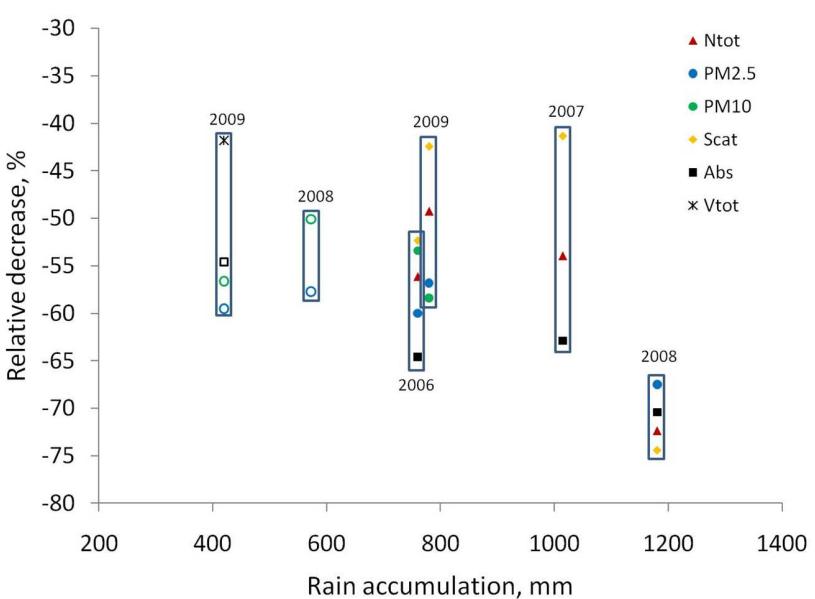

Fig. 3. The relative change of the aerosol concentrations from the pre-monsoon to monsoon season as a function of the JuneSeptember rain accumulation. Solid symbols: data from Mukteshwar; open symbols: data from Gual Pahari. Each year is surrounded by a box.

decreased to 0.50 , illustrating that aerosol aging processes started to take place.

From Gual Pahari, the average size distributions look rather different (Fig. 4c). During pre-monsoon, the nucleation- and Aitken-modes had a strong contribution, 

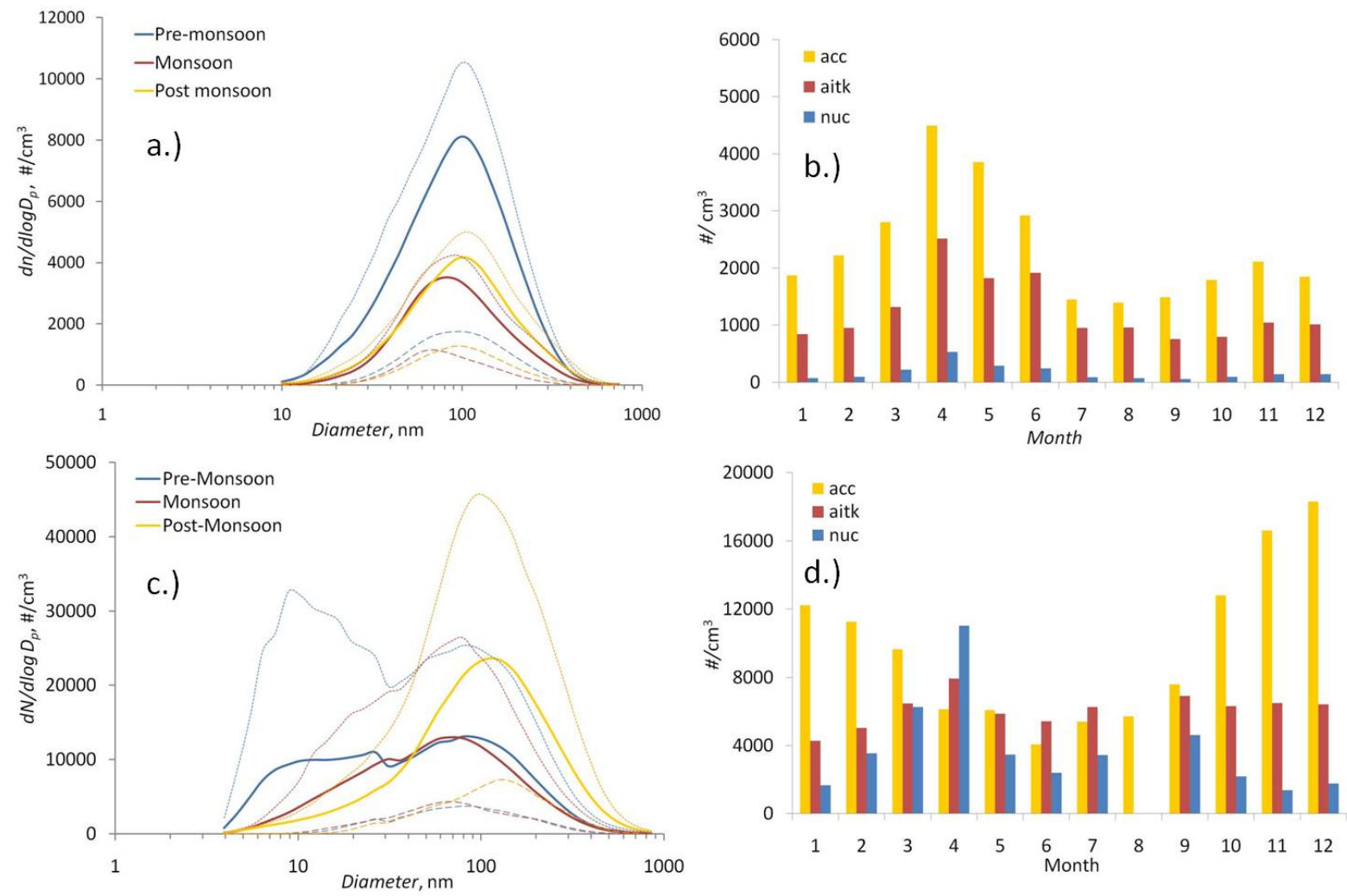

Fig. 4. Average size distributions for different seasons in (a) Mukteshwar, and (c) Gual Pahari. Solid lines are averages and dashed and dotted lines represent the 10th and 90th percentiles, respectively. Annual variation of the modal particle number concentrations in (b) Mukteshwar, and (d) Gual Pahari. Nucleation mode $d_{\mathrm{p}}<25 \mathrm{~nm}$, Aitken mode $25 \mathrm{~nm}<d_{\mathrm{p}}<75 \mathrm{~nm}$, accumulation mode $d_{\mathrm{p}}>75 \mathrm{~nm}$.

equal to the accumulation mode. This was due to strong new particle formation. The concentration decrease during the monsoon season was less obvious than in Mukteshwar, with the accumulation and Aitken-modes showing very similar values during both seasons (Fig. 4d). Also the nucleation mode concentration decreased only about $20 \%$, and new particle formation events were still observed. Despite the wet deposition, nucleation precursors apparently existed in Gual Pahari during the monsoon season. During monsoon, the accumulation mode diameter decreased from the pre-monsoon value of $\sim 80 \mathrm{~nm}$ to $\sim 70 \mathrm{~nm}$. The ratio $N_{\text {ait }} / N_{\text {acc }}$ was smaller than unity during both the pre-monsoon and the monsoon season, probably due to new particle formation and fresh emissions in the area. During post-monsoon season, similar aging of the aerosols took place as in Mukteshwar, resulting in an elevated accumulation mode, with $N_{\text {ait }} / N_{\text {acc }}<1$. It has to be emphasized that the data coverage from the Gual Pahari DMPS was very low, (lowest coverage during the monsoon season: $11 \%$ for the nucleation-, $34 \%$ for the Aitken- and $32 \%$ for the accumulation-mode), and the average size distributions do not necessarily represent the full seasons very well.

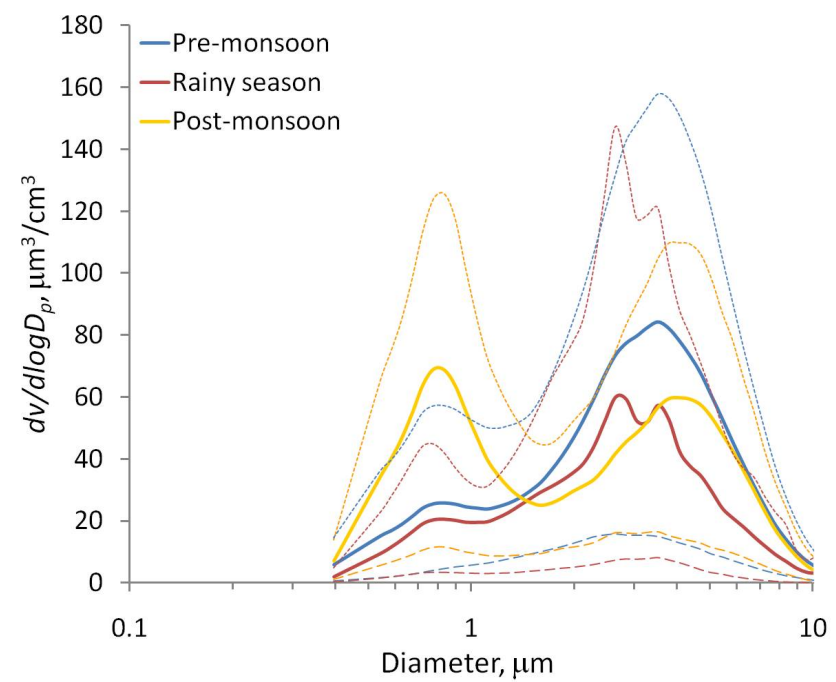

Fig. 5. The volume size distribution in Gual Pahari during different seasons, $0.4<d_{\mathrm{p}}<10 \mu \mathrm{m}$. Solid lines are averages and dashed and dotted lines represent the 10th and 90th percentiles, respectively. 

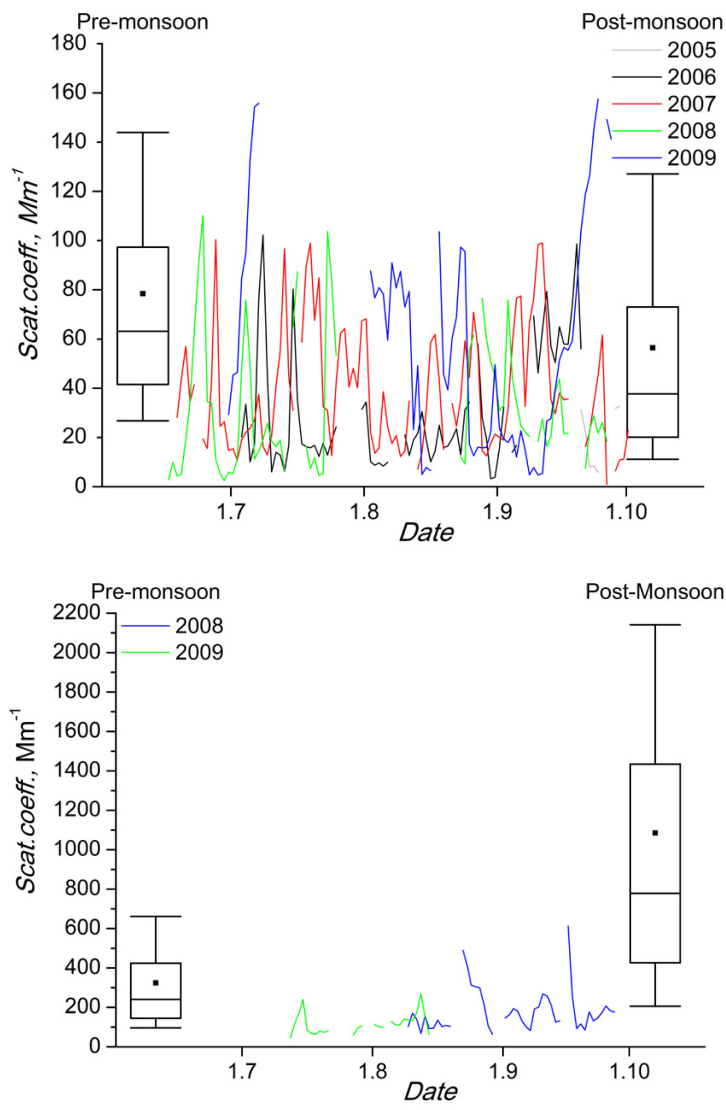

Fig. 6. Scattering coefficient (a) at $525 \mathrm{~nm}$ in Mukteshwar (b) at $520 \mathrm{~nm}$ in Gual Pahari. Lines are $24 \mathrm{~h}$ running averages from the monsoon season, box plots denote to pre- and post-monsoon seasonal values of $10 \%$-ile, $25 \%$-ile, median (line), average (dot), $75 \%$-ile and $90 \%$-ile.

When interpreting the size distribution data from the stations, two important aspects related to wet removal processes have to be kept in mind. First, the scavenging by rain is size dependent. The scavenging coefficient has a minimum for particles with a diameter around $150 \mathrm{~nm}$. With a near parabolic shape as a function of particle size, the scavenging coefficient is two times higher for $20 \mathrm{~nm}$ and for $\sim 2 \mu \mathrm{m}$ particles (e.g., Laakso et al., 2003). This helps to explain why accumulation particles in Gual Pahari were not lost very effectively. On the other hand, the mountain location of Mukteshwar promotes the occurrence of clouds and fogs, which enhance the removal of particles by the activation mechanism to cloud droplets. This mechanism is very effective for particles bigger than $100 \mathrm{~nm}$, and explains the accumulation mode decrease in Mukteshwar.

Volume size distributions were deducted from Gual Pahari APS-measurements in the aerodynamic size range of 0.4$10 \mu \mathrm{m}$ (Fig. 5) allowing for the inspection of larger particles. The average size distributions during pre-monsoon and monsoon seasons were strikingly similar (albeit lower in concen-
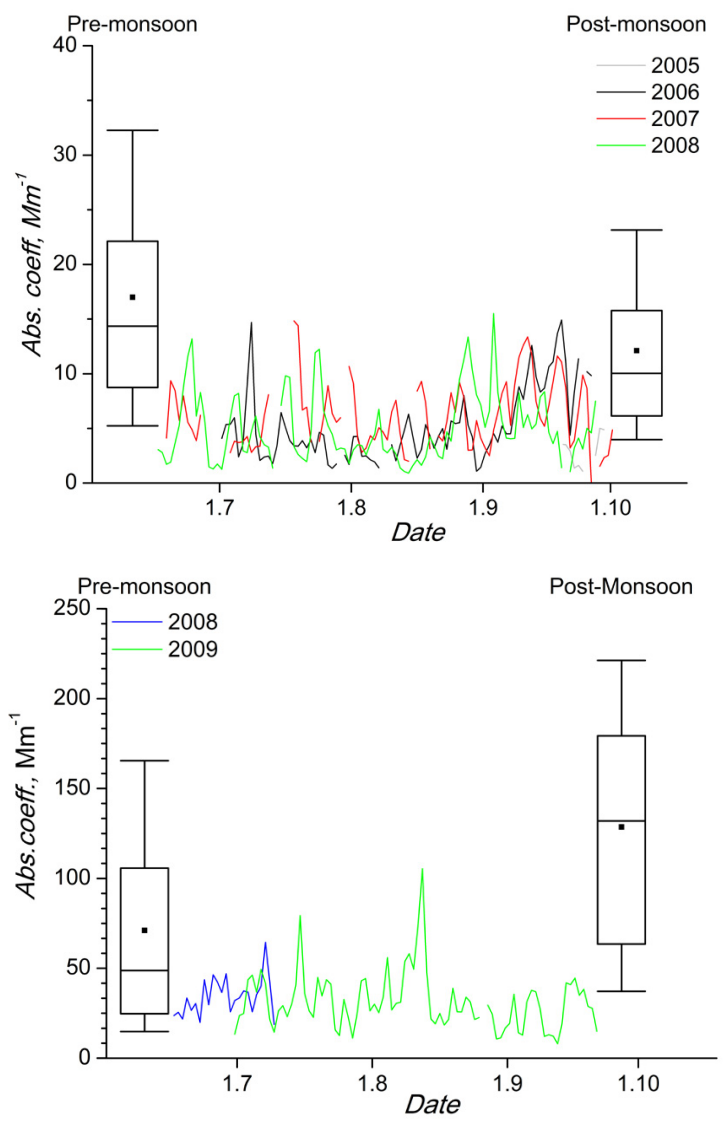

Fig. 7. Absorption coefficient (a) at $520 \mathrm{~nm}$ in Mukteshwar (b) at $637 \mathrm{~nm}$ in Gual Pahari. Lines are $24 \mathrm{~h}$ running averages from the monsoon season, box plots denote to pre- and post-monsoon seasonal values of $10 \%$-ile, $25 \%$-ile, median (line), average (dot), $75 \%$-ile and $90 \%$-ile.

tration during monsoon), with a coarse mode at $\sim 4 \mu \mathrm{m}$ during pre-monsoon and $\sim 3 \mu \mathrm{m}$ during monsoon. This mode is strongly related to primary particles, indicating that these were a prominent source during the pre-monsoon and monsoon season. The occurrence of the coarse mode also illustrates that sources are an important factor affecting the variability of aerosols during monsoon, not only the wet deposition loss processes. The contribution of mineral dust to the coarse mode was discussed in context of high concentration episodes during monsoon in the companion paper (Hyvärinen et al., 2011). A trajectory analysis conducted in that paper indicated that the origin of mineral dust was mainly from the Thar Desert. A smaller mode, which appears as a shoulder at $\sim 0.8 \mu \mathrm{m}$ was significantly higher during the post-monsoon season, exceeding the concentration of the coarse mode. This relates to the elevated accumulation mode during post-monsoon. 

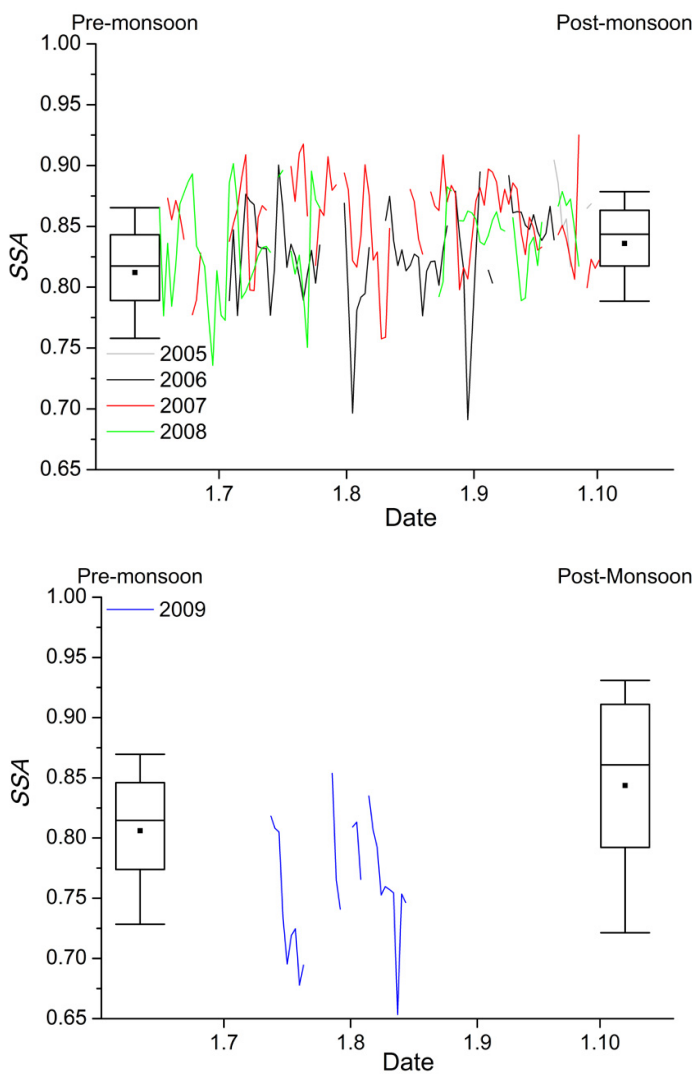

Fig. 8. Single scattering albedo, SSA at $525 \mathrm{~nm}$. (a) Mukteshwar (b) Gual Pahari. Lines are $24 \mathrm{~h}$ running averages from the monsoon season, box plots denote to pre- and post-monsoon seasonal values of $10 \%$-ile, $25 \%$-ile, median (line), average (dot), $75 \%$-ile and $90 \%$-ile.

\subsection{Aerosol scattering and absorption coefficient}

The optical properties (Figs. 6 and 7) generally followed the seasonal behaviour of concentration levels decreasing between $40-75 \%$ from the pre-monsoon average during monsoon (Table 1 and Fig. 3). In Mukteshwar, the scattering coefficient decreased, on average, less than the absorption coefficient (Fig. 3), mostly due to episodic peak concentrations (Fig. 6) during the monsoon season. Light scattering is more effective, the bigger the particles are. So, again the increased light scattering can be related to mineral dust which was occasionally present during the break spells of the monsoon. The more effective decrease of the absorption coefficient indicates an efficient removal of absorbing aerosols in Mukteshwar. As discussed in the previous section, cloud and fog occurrence provided an additional activation mechanism for aerosol removal in Mukteshwar. The effective decrease of the absorption coefficient implies that the absorbing material was in a hygroscopic form, thus, favouring the activation process.

In Gual Pahari, less data is available for the monsoon time scattering and absorption coefficients. It is notable that,

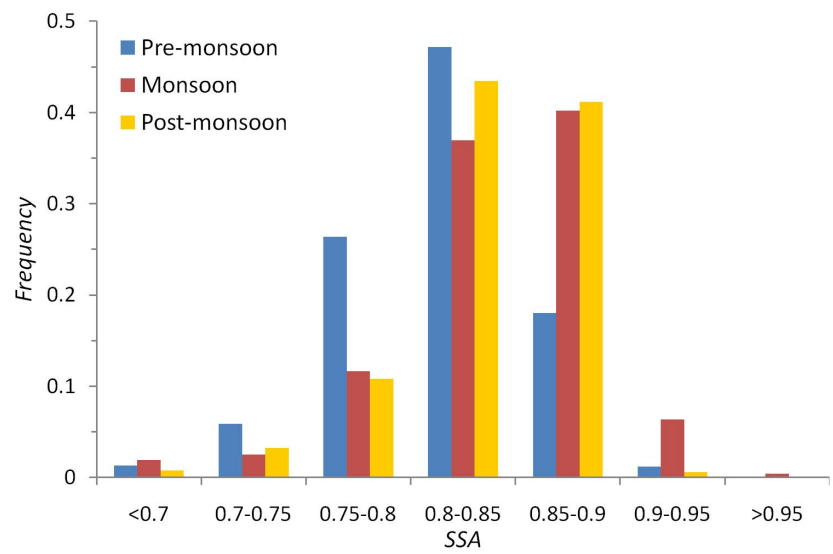

Fig. 9. Histogram of SSA values in Mukteshwar during premonsoon, monsoon and post-monsoon.

similarly to Mukteshwar, scattering coefficient showed occasional high concentrations, especially during 2009 (Fig. 6). In contrast to Mukteshwar, absorption coefficient in $\mathrm{Gual} \mathrm{Pa}$ hari did not decrease very efficiently (Fig. 3) in the monsoon season. This can be explained by two reasons: first, the accumulation mode with the related absorbing particles was less effectively decreased during the monsoon in Gual Pahari, because of the missing activation removal mechanism. Second, Gual Pahari is located closer to pronounced anthropogenic combustion sources. This can be observed by the occasionally high absorption coefficients (Fig. 7), and in general the high $N_{\text {ait }} / N_{\text {acc }}$ ratio above unity supports this.

During post-monsoon, a clear difference can be seen at the two stations - at Mukteshwar, both the absorption and scattering coefficient decreased compared to pre-monsoon, while in Gual Pahari a substantial increase was observed. As mentioned before, this is related to the boundary layer evolution, as most of the pollution was confined below the altitude of Mukteshwar. This is studied in more detail by Raatikainen et al. (2010).

\subsection{Single scattering albedo}

We calculated the single scattering albedo, SSA from the scattering and absorption coefficients measured at both stations. Single scattering albedo is the ratio of the scattering coefficient to the extinction coefficient (scattering + absorption). In Mukteshwar, the single scattering albedo had values of $0.75-0.90$ (Fig. 8), being slightly higher during the monsoon season than during the other seasons. The wide range of SSA values illustrates that the aerosol was highly variable in terms of optical properties. Looking at the Mukteshwar data in more detail (Fig. 9), we notice that a higher frequency of low SSA values was observed during the pre-monsoon season. This indicates the abundance of absorbing aerosols, which may originate from anthropogenic combustion sources or from the seasonal forest fires in the area. During monsoon 


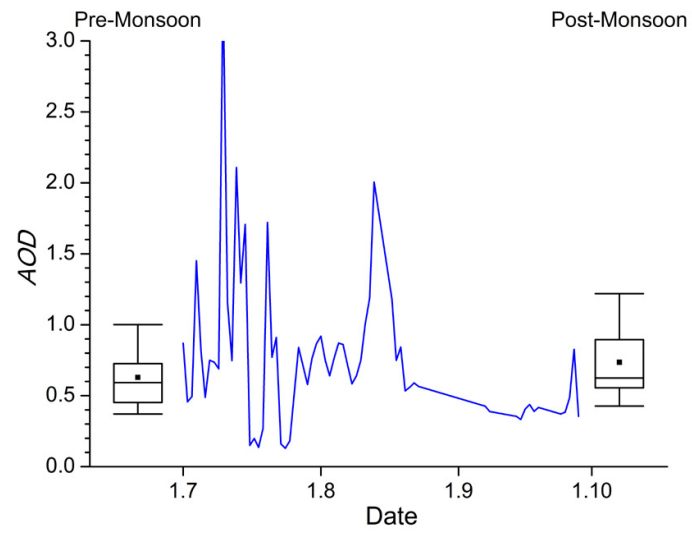

Fig. 10. Aerosol optical depth, AOD at $500 \mathrm{~nm}$, measured with the Cimel sunphotometer during 2009 in Gual Pahari. Line is daily averages, box plots denote pre- and post-monsoon seasonal values of $10 \%$-ile, $25 \%$-ile, median (line), average (dot), $75 \%$-ile and $90 \%$ ile.

season, a small fraction ( $\sim 5 \%)$ of SSA values higher than 0.9 were also observed. These high values corresponded mostly with the higher scattering coefficients and were probably related to mineral dust. The fact that high SSA values were not observed during the pre-monsoon even though this is also the season for dust events suggests that during premonsoon the mineral dust was mixed with other, more absorbing aerosol. Some episodes during the monsoon season showed decreased SSA of about 0.70 , indicating highly absorbing aerosol. This occurred only with low absorption and scattering coefficients, and was probably from local sources, such as cooking (Hyvärinen et al., 2009). We also compared the SSA against the total particle count $N_{\text {tot }}$ from Mukteshwar. As a general finding, the SSA values converged towards 0.9 as $N_{\text {tot }}$ increased.

The SSA in Gual Pahari showed slightly lower values than in Mukteshwar, especially during the pre-monsoon, varying from 0.73 to 0.93 , with a majority of SSA values $(37 \%)$ falling between 0.8 and 0.85 . This is hardly surprising, as many anthropogenic sources produce $\mathrm{BC}$ in the area. There is very little information about the SSA in Gual Pahari during the monsoon, but the values observed were typically below 0.8 , indicating the dominance of absorbing particles. Reasons for the dominance of absorbing particles were discussed in the previous section. Firm conclusions cannot be made from the Gual Pahari monsoon time SSA due to the poor data coverage. For the post-monsoon, the average SSA increased compared to pre-monsoon at both locations. No significant inter-annual variation was observed in the SSA data.

\subsection{Aerosol columnar properties}

Aerosol columnar properties were observed at Gual Pahari. During 2008, a Raman lidar was installed (Komppula et al., 2010) and during 2009 a Cimel Sunphotometer. The sunpho- tometer data we present here are level 1.5 data, which means that the data is cloud screened, but some quality checks are missing. The average AOD measured with the sunphotometer at $500 \mathrm{~nm}$ during the pre-monsoon was about 0.61 in Gual Pahari (Fig. 10). During the monsoon season the average AOD increased to about 0.70 . It is noted that these are daytime values.

The aerosol columnar properties show a different seasonal behaviour compared to the surface measurements, with the AOD having a maximum in the early monsoon season (Fig. 10). This observation is supported by the Lidar heightresolved profiles which show that the aerosol backscatter and extinction were at elevated levels during the monsoon season (Fig. 11). These profiles show that during the premonsoon and monsoon seasons the aerosol backscatter was highest in the lower altitudes, below $2 \mathrm{~km}$, and decreased monotonically with altitude. During post-monsoon season, a low-level, but thick aerosol layer was observed. This corresponds well with the boundary layer height (Raatikainen et al., 2011), which implies that during the pre-monsoon the aerosol would be efficiently vertically mixed, opposite to post-monsoon. However, the boundary layer height does not explain the aerosol vertical distribution during the monsoon season.

This illustrates that the columnar measurements during the monsoon season, their interpretation and comparison to ground-level measurements is not a straightforward task. The conflict between the average boundary layer heights may be explained by the fact that during the break spells of the monsoon (and, thus, times when the columnar measurements were actually conducted), the boundary layer heights are elevated compared to the average values (Kusuma et al., 1991). This still does not solve the discrepancy between surface in situ and columnar measurements. As noted in Hyvärinen et al. (2011), dust episodes were a probable reason for the early monsoon high concentrations. We studied this prospect by analysing the refractive index data from the sunphotometer measurements (Fig. 12). The real part of the refractive index obtained values mostly above 1.47. This corresponds well with mineral dust (mixed with other aerosol), which has a refractive index of about 1.5 (e.g., d'Almeida et al., 1991). The AOD's during the early monsoon showed much higher values than during pre-monsoon, when mineral dust was also present in surface measurements. Relative humidity may provide an explanation in the observed discrepancies, as it affects the particle size and, thus, its optical properties (Zieger et al., 2011). While the columnar measurements provide properties of ambient aerosol, the in situ measurements are from a dried aerosol. Drying may reduce the particle sizes by a factor of $2-4$, depending on aerosol composition and ambient conditions.

We tested this hypothesis by comparing the Lidar extinction profiles with $\mathrm{RH}$ soundings available for the $\mathrm{Li}$ dar measurement periods from the near-by New Delhi airport (Fig. 13) (University of Wyoming, department 

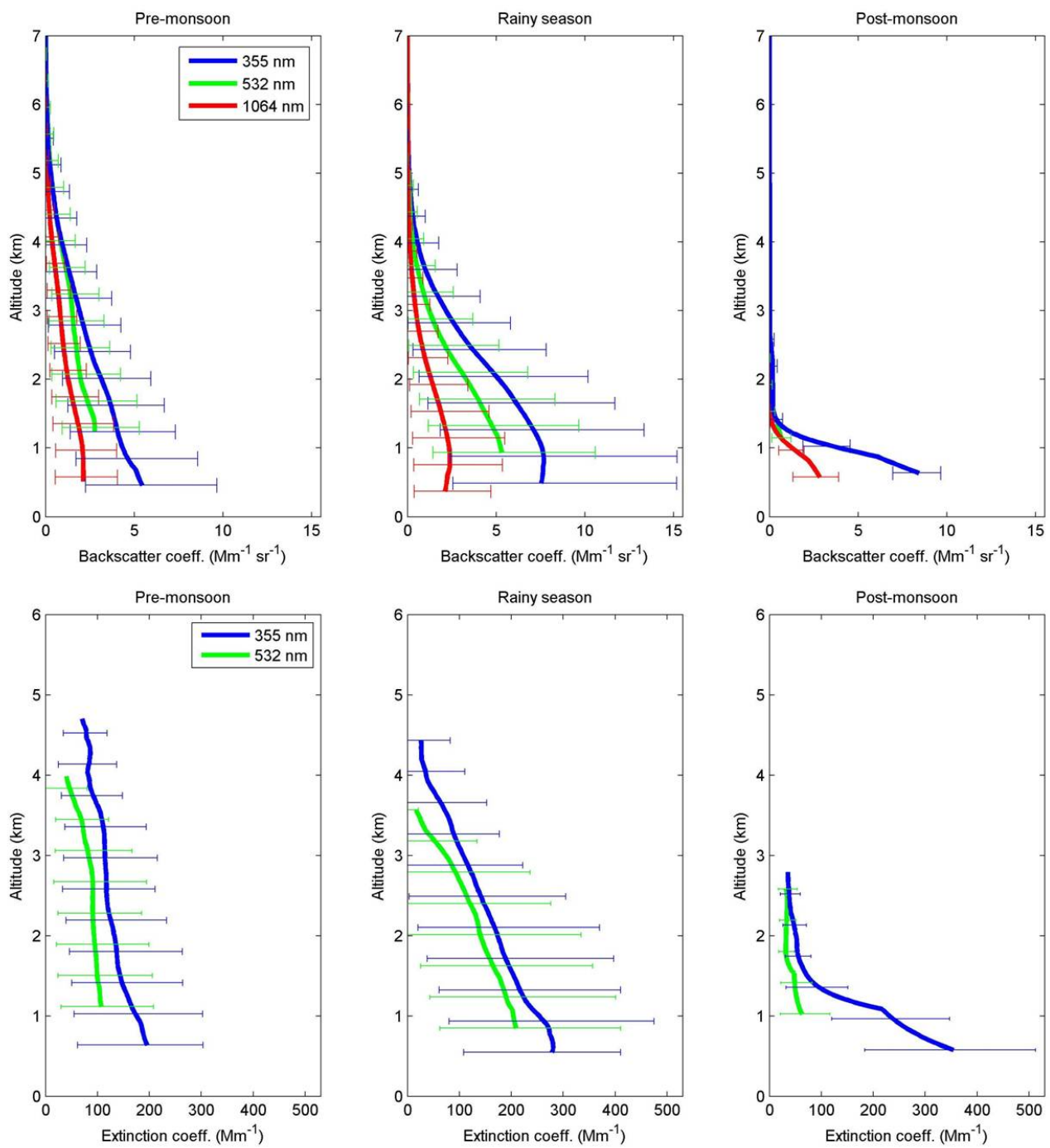

Fig. 11. Seasonal averaged backscatter and extinction profiles at two wavelengths for the Gual Pahari site during 2008 . The 10 and 90 percentiles are also shown.

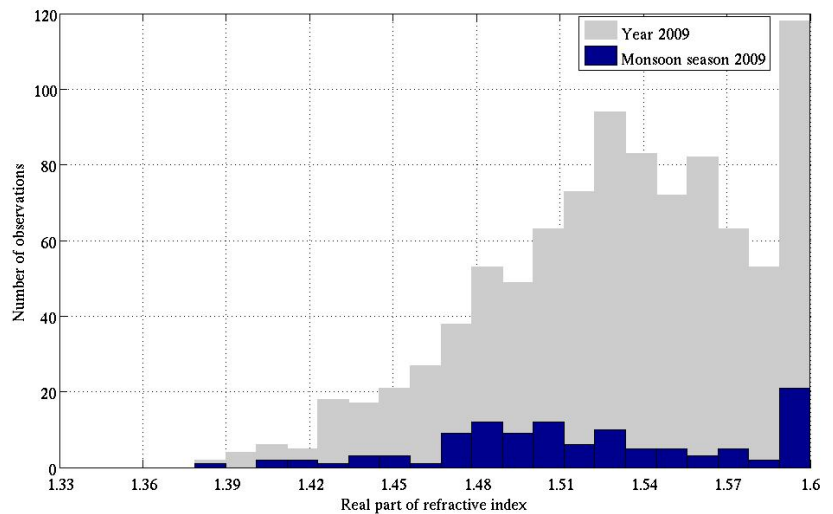

Fig. 12. Histogram of (real part) refractive index from Gual Pahari sunphotometer measurements during 2009. of atmospheric research, http://weather.uwyo.edu/upperair/ sounding.html). It can be seen that the profiles are very similar. This could well be a reason for the discrepancy between surface in situ and columnar measurements. However, to quantify the effect will be difficult without state-of-the-art instruments such as the hygroscopic tandem DMA or a humidified nephelometer. Another explanation for the differences could be that high concentration aerosols, such as mineral dust, occur at higher altitudes rather than near the surface. Indeed, the maximum extinction observed in the Lidar profiles occurred at around $1 \mathrm{~km}$ altitude. Another reason for the observed differences could be that the columnar measurements were only conducted during cloud free periods. However, comparing the in situ concentrations only when AOD was measured did not solve the difference. 

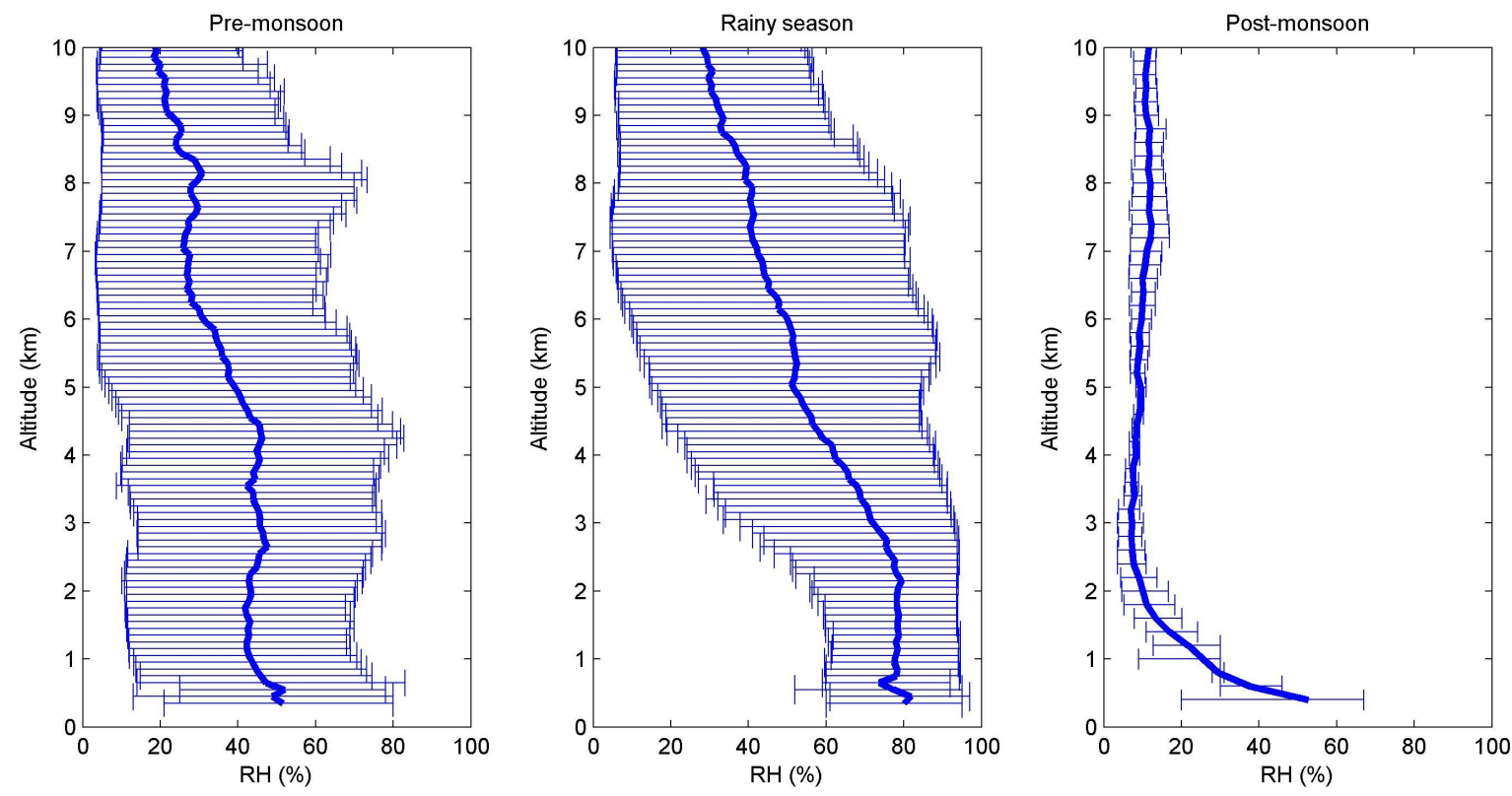

Fig. 13. Seasonal averaged RH-profiles from soundings at New Delhi airport during 2008 for the same time periods the lidar data was available. The 10th and 90th percentiles are also shown.

\section{Conclusions}

A 4-yr data set from Mukteshwar, Indian Himalayas, and a 2-yr data set from Gual Pahari, Indo-Gangetic plains, was utilized to study the variation of aerosol physical and optical properties before, during and after the monsoon. We observed that at both stations, the average monsoon aerosol concentrations were smaller by $40-75 \%$ compared to the pre-monsoon average concentrations, decreasing with increasing total local rainfall during the monsoon season.

In Mukteshwar, there were two major wet removal mechanisms: aerosol scavenging by falling rain drops and activation to cloud and mountain fog droplets. The former mechanism removed other than accumulation mode particles effectively, while the latter mechanism was especially effective in removing the accumulation mode and bigger particles. Thus, the monsoon removed particles in all size classes. In Gual Pahari, the main removal mechanism was scavenging by rain. The accumulation mode was less effectively removed than the smaller and larger particles. Consequently, in Mukteshwar, black carbon (being mostly in the accumulation mode) decreased effectively during the monsoon season, resulting in decreased absorption over scattering. In Gual Pahari, accumulation mode BC was less effectively removed. Thus, the single scattering albedo increased in Mukteshwar during the monsoon season, but decreased in Gual Pahari.

In addition to the loss processes, aerosol concentrations during the monsoon were affected by sources. In Gual Pahari, new particle formation was observed during the premonsoon and monsoon seasons. In both locations, mineral dust was observed. This resulted in an elevated $\mathrm{PM}_{10}$ concentration at both stations (Hyvärinen et al., 2011), and a dominating volume mode at 3-4 $\mu \mathrm{m}$ observed with the APS in Gual Pahari. The occurrence of mineral dust was further evinced by an increased scattering coefficient at both stations, and a refractive index $\sim 1.5$ was observed with the Gual Pahari sunphotometer. The contribution of mineral dust during these months has been reported also previously (e.g., Dey and Tripathi, 2008; Gautam et al., 2009b, 2011; Ram et al., 2008, 2010). It is likely that the relatively high absorption coefficients in Gual Pahari (and corresponding low SSA values) during the monsoon season were partly caused by the pronounced anthropogenic combustion sources in the area.

The aerosol columnar properties, which were measured in Gual Pahari, had an annual maximum in the early monsoon season, which is in contradiction with the surface measurements. We concluded two likely reasons for this: (1) Columnar measurements were from the ambient aerosol (grown by water vapour), while the in situ measurements sampled dry aerosol. (2) The early monsoon dust events arrived from a higher altitude as indicated by the maximum extinction with the Lidar at around $1 \mathrm{~km}$ altitude.

\section{Supplementary material related to this article is available online at: http://www.atmos-chem-phys.net/11/8283/2011/ acp-11-8283-2011-supplement.pdf.}


Acknowledgements. Measurements in the Gual Pahari station were funded by the The European Integrated project on Aerosol Cloud Climate and Air Quality Interactions, EUCAARI. Mukteshwar measurements were funded by The Ministry of Foreign Affairs of Finland, "Particulate pollution and the Indian Brown Cloud associated with it" - project. Timo Anttila and Ari Halm are acknowledged for technical assistance and Juha Hatakka for trajectory calculations. TERIs staff is acknowledged for their valuable routine maintenance of instruments in Gual Pahari and Mukteshwar stations, and for the synoptic weather observations at the Mukteshwar station.

Edited by: A. Wiedensohler

\section{References}

Bergstrom, R. W.: Extinction and Absorption Coefficients of the Atmospheric Aerosol as a Function of Particle Size, Contr. Atmos. Phys., 46, 223-234, 1973.

Bergstrom, R. W., Pilewskie, P., Russell, P. B., Redemann, J., Bond, T. C., Quinn, P. K., and Sierau, B.: Spectral absorption properties of atmospheric aerosols, Atmos. Chem. Phys., 7, 5937-5943, doi:10.5194/acp-7-5937-2007, 2007.

Bollasina, M., Nigam, S., and Lau, K.-M.: Absorbing Aerosols and Summer Monsoon Evolution over South Asia: An Observational Portrayal, J. Climate, 21, 3221-3239, 2008.

Bohren, C. F. and Huffman, D. R.: Absorption and scattering of light by small particles, John Wiley and Sons, New York, 530 pp., 1983.

Chang, M.-C., Chow, O., J. C., Watson, J. G., Hopke, P. K., Yi, S.M., and England, G. C.: Measurements of ultrafine particle size distributions from coal-, oil- and gas-fired stationary combustion sources, J. Air Waste Manage. Assoc., 54, 1494-1505, 2004.

Collier, J. C. and Zhang, G. J.: Aerosol direct forcing of the summer Indian monsoon as simulated by the NCAR CAM3, Clim. Dynam., 32, 313-332, 2009.

d'Almeida, G. A., Koepke, P., and Shettle, E. P.: Atmospheric aerosols: Global climatology and radiative characteristics, A Deepak Publishing, Hampton, Virginia, 561 pp., 1991.

Dey, S. and Tripathi, S. N.: Aerosol direct radiative effects over Kanpur in the Indo-Gangetic basin, northern India: Long-term (2001-2005) observations and implications to regional climate, J. Geophys. Res., 113, D04212, doi:10.1029/2007JD009029, 2008.

Gautam, R., Hsu, N. C., Lau, K.-M., Tsay, S. C., and Kafatos, M.: Enhanced pre-monsoon warming over the Himalayan-Gangetic region from 1979 to 2007, Geophys. Res. Lett., 36, L07704, doi:10.1029/2009GL037641, 2009a.

Gautam, R., Hsu, N. C., Lau, K.-M., and Kafatos, M.: Aerosol and rainfall variability over the Indian monsoon region: distributions, trends and coupling, Ann. Geophys., 27, 3691-3703, doi:10.5194/angeo-27-3691-2009, 2009b.

Gautam, R., Hsu, N. C., Tsay, S. C., Lau, K. M., Holben, B., Bell, S., Smirnov, A., Li, C., Hansell, R., Ji, Q., Payra, S., Aryal, D., Kayastha, R., and Kim, K. M.: Accumulation of aerosols over the Indo-Gangetic plains and southern slopes of the Himalayas: distribution, properties and radiative effects during the 2009 pre-monsoon Season, Atmos. Chem. Phys. Discuss., 11, 15697-15743, doi:10.5194/acpd-11-15697-2011, 2011.
Holben, B. N., Eck, T. F., Slutsker, I., Tanre, D., Buis, J. P., Setzer, A., Vermote, E., Reagan, J. A., Kaufman, Y. J., Nakajima, T., Lavenu, F., Jankowiak, I., and Smirnov, A.: AERONET A Federated Instrument Network and Data Archive for Aerosol Characterization, Remote Sens. Environ. 66, 1-16, 1998.

Huang, Y., Chameides, W. L., and Dickinson, R. E.: Direct and indirect effects of anthropogenic aerosols on regional precipitation over east Asia, J. Geophys. Res. 112, D03212, doi:10.1029/2006JD007114, 2007.

Hyvärinen, A.-P, Lihavainen, H., Komppula, M., Sharma, V. P., Kerminen, V.-M., Panwar, T. S., and Viisanen, Y.: Continuous measurements of optical properties of atmospheric aerosols in Mukteshwar, Northern India, J. Geophys. Res., 114, D08207, doi:10.1029/2008JD011489, 2009.

Hyvärinen, A.-P., Lihavainen, H., Komppula, M., Panwar, T. S., Sharma, V. P., Hooda, R. K., and Viisanen, Y.: Aerosol measurements at the Gual Pahari EUCAARI station: preliminary results from in-situ measurements, Atmos. Chem. Phys., 10, 72417252, doi:10.5194/acp-10-7241-2010, 2010.

Hyvärinen, A.-P., Raatikainen, T., Brus, D., Komppula, M., Panwar, T. S., Hooda, R. K., Sharma, V. P., and Lihavainen, H.: Effect of the summer monsoon on aerosols at two measurement stations in Northern India - Part 1: PM and BC concentrations, Atmos. Chem. Phys., 11, 8271-8282, doi:10.5194/acp-11-82712011, 2011.

Komppula, M., Lihavainen, H., Hyvärinen, A.-P., Kerminen, V.-M., Panwar, T. S., Sharma, V. P., and Viisanen, Y.: Physical properties of aerosol particles at a Himalayan background site in India, J. Geophys. Res., 114, D12202, doi:10.1029/2008JD011007, 2009.

Komppula, M., Mielonen, T., Arola, A., Korhonen, K., Lihavainen, H., Hyvärinen, A.-P., Baars, H., Engelmann, R., Althausen, D., Ansmann, A., Müller, D., Panwar, T. S., Hooda, R. K., Sharma, V. P., Kerminen, V.-M., Lehtinen, K. E. J., and Viisanen, Y.: One year of Raman-lidar measurements in Gual Pahari EUCAARI site close to New Delhi in India: seasonal characteristics of the aerosol vertical structure, Atmos. Chem. Phys. Discuss., 10, 31123-31151, doi:10.5194/acpd-10-31123-2010, 2010.

Kuhlmann, J. and Quaas, J.: How can aerosols affect the Asian summer monsoon? Assessment during three consecutive premonsoon seasons from CALIPSO satellite data, Atmos. Chem. Phys., 10, 4673-4688, doi:10.5194/acp-10-4673-2010, 2010.

Kusuma, G. R., Raman, S., and Prabhu, A.: Boundary-layer heights over the monsoon trough region during active and break phases, Bound.-Layer Meteorol., 57, 129-138, 1991.

Laakso, L., Grönholm, T., Rannik, Ü, Kosmale, M., Fiedler, V., Vehkamäki, H., and Kulmala, M.: Ultrafine particle scavenging coefficients calculated from 6 years field measurements, Atmos. Environ., 37, 3605-3613, 2003.

Lau, K. M. and Kim, K.-M.: Observational relationship between aerosol and Asian rainfall and circulation, Geophys. Res. Lett., 33, L21810, doi:10.1029/2006GL027546, 2006.

Lau, K. M. and Kim, K.-M.: Fingerprinting the impacts of aerosols on long-term trends of the Indian summer monsoon regional rainfall, Geophys. Res. Lett., 37, L16705, doi:10.1029/2010GL043255, 2010.

Lau, K. M., Kim, M. K., and Kim, K.-M.: Asian monsoon anomalies induced by aerosol direct effects, Clim. Dyn., 26, 855-864, doi:10.1007/s00382-006-0114-z, 2006. 
Lelieveld, J., Crutzen, P. J., Ramanathan, V., Andreae, M. O., Brenninkmeijer, C. A. M., Campos, T., Cass, G. R., Dickerson, R. R., Fischer, H., de Gouw, J. A., Hansel, A., Jefferson, A., Kley, D., de Laat, A. T. J., Lal, S., Lawrence, M. G., Lobert, J. M., MayolBracero, O. L., Mitra, A. P., Novakov, T., Oltmans, S. J., Prather, K. A., Reiner, T., Rodhe, H., Scheeren, H. A., Sikka D., and Williams, J.: The Indian Ocean Experiment: Widespread air pollution from South and Southeast Asia, Science 291, 1031-1036, 2001.

Liu, D., Wang, Z., Liu, Z., Winker, D., and Trepte, C.: A height resolved global view of dust aerosols from the first year CALIPSO lidar measurements, J. Geophys. Res., 113, D16214, doi:10.1029/2007JD009776, 2008.

Liu, Z., Liu, D., Huang, J., Vaughan, M., Uno, I., Sugimoto, N., Kittaka, C., Trepte, C., Wang, Z., Hostetler, C., and Winker, D.: Airborne dust distributions over the Tibetan Plateau and surrounding areas derived from the first year of CALIPSO lidar observations, Atmos. Chem. Phys., 8, 5045-5060, doi:10.5194/acp-85045-2008, 2008.

Meehl, G. A., Arblaster, J. M., and Collins, W. D.: Effects of Black Carbon Aerosols on the Indian Monsoon, J. Climate, 21, 28692882, 2008.

Müller, T., Henzing, J. S., de Leeuw, G., Wiedensohler, A., Alastuey, A., Angelov, H., Bizjak, M., Collaud Coen, M., Engström, J. E., Gruening, C., Hillamo, R., Hoffer, A., Imre, K., Ivanow, P., Jennings, G., Sun, J. Y., Kalivitis, N., Karlsson, H., Komppula, M., Laj, P., Li, S.-M., Lunder, C., Marinoni, A., Martins dos Santos, S., Moerman, M., Nowak, A., Ogren, J. A., Petzold, A., Pichon, J. M., Rodriquez, S., Sharma, S., Sheridan, P. J., Teinilä, K., Tuch, T., Viana, M., Virkkula, A., Weingartner, E., Wilhelm, R., and Wang, Y. Q.: Characterization and intercomparison of aerosol absorption photometers: result of two intercomparison workshops, Atmos. Meas. Tech., 4, 245-268, doi:10.5194/amt-4-245-2011, 2011.

Nakajima, T., Yoon, S.-C., Ramanathan, V., Shi, G.-Y., Takemura, T., Higurashi, A., Takamura, T., Aoki, K., Sohn, B.-J., Kim, S.-W., Tsuruta, H., Sugimoto, N., Shimizu, A. Tanimoto, H., Sawa, Y., Lin, N.-H., Lee, C.-T., Goto, D., and Schutgens, N.: Overview of the atmospheric Brown Cloud East Asian Regional Experiment 2005 and a study of the aerosol direct radiative forcing in east Asia, J. Geophys. Res., 112, D24S91, doi:10.1029/2007JD009009, 2007.

Neitola, K., Asmi, E., Komppula, M., Hyvärinen, A.-P., Raatikainen, T., Panwar, T. S., Sharma, V. P., and Lihavainen, H.: New particle formation infrequently observed in Himalayan foothills - why?, Atmos. Chem. Phys. Discuss., 11, 1319313228, doi:10.5194/acpd-11-13193-2011, 2011.
Nigam, S. and Bollasina, M.: "Elevated heat pump" hypothesis for the aerosol-monsoon hydroclimate link: "Grounded" in observations?, J. Geophys. Res., 115, D16201, doi:10.1029/2009JD013800, 2010.

Raatikainen, T., Hyvärinen, A.-P., Hatakka, J., Panwar, T. S., Hooda, R. K., Sharma, V. P., and Lihavainen, H.: Comparison of aerosol properties from the Indian Himalayas and the Indo-Gangetic plains, Atmos. Chem. Phys. Discuss., 11, 1141711453, doi:10.5194/acpd-11-11417-2011, 2011.

Ram, K., Sarin, M. M., and Hedge, P.: Atmospheric abundances of primary and secondary carbonaceous species at two high-altitude sites in India : Sources and temporal variability, Atmos. Environ., 42(28), 6785-6796, 2008.

Ram, K., Sarin, M. M., and Tripathi, S. N.: A 1 year record of carbonaceous aerosols from an urban site in the Indo-Gangetic Plain: Characterization, sources, and temporal variability, J. Geophys. Res., 115, D24313, doi:10.1029/2010JD014188, 2010.

Ramanathan, V. and Carmichael, G.: Global and regional climate changes due to black carbon, Nat. Geosci., 1, 221-227, 2008.

Ramanathan, V., Li, F., Ramana, M. V., Praveen, P. S., Kim, D., Corrigan, C. E., Nguyen, H., Stone, E. A., Schauer, J. J., Carmichael, G. R., Adhikary, B., and Yoon, S. C.: Atmospheric brown clouds: Hemispherical and regional variations in longrange transport, absorption, and radiative forcing, J. Geophys. Res., 112, D22S21, doi:10.1029/2006JD008124, 2007.

Randles, C. A. and Ramaswamy, V.: Absorbing aerosols over Asia: A Geophysical Fluid Dynamics Laboratory general circulation model sensitivity study of model response to aerosol optical depth and aerosol absorption, J. Geophys. Res., 113, D21203, doi:10.1029/2008JD010140, 2008.

Tyagi, A., Hatwar, H. R., and Pai, D. S., eds.: Monsoon 2008, A report, Government of India, India Meteorological Department, 2009.

Zieger, P., Weingartner, E., Henzing, J., Moerman, M., de Leeuw, G., Mikkilä, J., Ehn, M., Petäjä, T., Clémer, K., van Roozendael, M., Yilmaz, S., Frieß, U., Irie, H., Wagner, T., Shaiganfar, R., Beirle, S., Apituley, A., Wilson, K., and Baltensperger, U.: Comparison of ambient aerosol extinction coefficients obtained from in-situ, MAX-DOAS and LIDAR measurements at Cabauw, Atmos. Chem. Phys., 11, 2603-2624, doi:10.5194/acp11-2603-2011, 2011. 